\title{
Probable ATP-Dependent RNA Helicase DDX52
}

National Cancer Institute

\section{Source}

National Cancer Institute. Probable ATP-Dependent RNA Helicase DDX52. NCI

Thesaurus. Code C106435.

Probable ATP-dependent RNA helicase DDX52 (599 aa, $\sim 67 \mathrm{kDa}$ ) is encoded by the human DDX52 gene. This protein plays a role in both RNA binding and AT Pase activity. 